\title{
Perspectives on the Improving Quality of Language Education: The Case of Moscow Aviation Institute
}

\author{
Irina Korotaeva*, Oksana Chuksina \\ Institute of Foreign languages, Moscow Aviation Institute (National Research University), Russia
}

Received April 6, 2020 ; Revised May 30, 2020; Accepted July 27, 2020

Copyright $\mathrm{O} 2020$ by authors, all rights reserved. Authors agree that this article remains permanently open access under the terms of the Creative Commons Attribution License 4.0 International License

\begin{abstract}
At present, The Unified State Exam in foreign languages is taken only by the applicants of Russian language universities and faculties, but it will become obligatory for everybody in 2022 regardless of the choice of their future specialty. In the run-up of this innovation, we have conducted a survey to determine the correlation between the quality of language education in non-linguistic universities and the students' experience of learning English before the University. Russian and international standards of engineering education are discussed in the article in terms of the communicative competence. We compare the target skills of the Unified State Exam and the English program for non-linguistic universities. The aim of our work is to show that the high requirements for foreign language competence of graduates of non-linguistic universities can be achieved if the English level of the applicants is improved. It is highlighted that the effective use of progressive methods of teaching a foreign language is hampered in multi-level mixed-ability classes. The research sample consisted of 517 students; it was conducted in the Department of Foreign Languages for Aerospace Specialties in Moscow Aviation Institute. The results of the survey illustrate the actual quality of language education of the students and their motivation to learn General, Academic, Business and Aviation English at the university at an upgraded level.
\end{abstract}

Keywords Quality of Education, The Unified State Exam in Foreign Languages, A Curricular in Foreign Languages for Non-linguistic Universities, Engineering Education Standards

\section{Introduction}

It is a well-known fact that the quality of language education at higher institutions in Russia doesn't correspond to the modern requirements at the work place.
Researchers have highlighted the importance of applying new communicative methods as well as implementing education reforms to improve the teaching and learning of English language [1].There is little research that focuses on the relationship between the quality of language education at higher institutions and the students' prior experience of learning English at school. It might be claimed that that the quality of foreign language education will improve if this relationship is recognized. Currently students take the exam in a foreign language only if they choose to apply language universities and faculties. In 2022 all school-leavers will take either basic or profile level of complexity of the Unified State Exam in foreign language. It is still disputable how technical universities or so-called "non-linguistic universities" can benefit from this innovation.

In non-linguistic universities students follow "continuous professional training in a foreign language while mastering a particular specialty (school - technical school - university - postgraduate education). The final requirements of one course are at the same time the starting requirements for studying the next course" [2]. It seems, there is a correlation between the level of proficiency in a foreign language of applicants and preparation for the exam. Teaching a foreign language in non-linguistic universities is aimed to upgrade the quality of language training for engineers.

The purpose of this article is to characterize the actual quality of language education in technical universities and analyze the program requirements for the Unified State Exam in a foreign language. We believe that the data obtained as a result of our research in Moscow Aviation Institute can be considered typical for many Russian technical universities, as our applicants come from different regions of our country.

According to L. I. Fishman the characteristics of the quality of educational services by L.I. Fishman are the results of education and conditions of the educational process [3]. 
Let us consider the quality of language education in technical university in terms of the expected results and the actual conditions of the educational process. Moscow Aviation Institute implements engineering education standards of the worldwide CDIO initiative (Conceive Design - Implement - Operate). Graduates must be capable of integrated engineering activities: to plan, design, produce, and apply engineering products, processes and systems in a modern environment based on the teamwork of specialists. Engineering education at the present stage is designed to ensure the development and implementation of the life cycle of products, processes and systems. At the same time educational institutions should consistently apply predetermined and published rules covering all stages of the student's "life cycle", such as student admissions, training and certification [4].

To analyze the role and significance of the discipline "Foreign Language" in the engineers training, we can refer to the current standards of higher professional education and foreign language programs for non-linguistic universities. The discipline "foreign language" is included into the basic part of the undergraduate program of training engineers for Aircraft industry and is compulsory for all students regardless of the specialty they master. A graduate who has mastered the bachelor's program must develop general and professional competencies. It follows from the standard that foreign language proficiency does not fall within the core competencies of the engineers in Aircraft industry. The graduate is expected "to master a foreign language to be able to speak fluently". According to the program the engineers should "prepare data for surveys, reports and scientific publications", which may involve reading foreign publications in specialty. In addition, bachelors in aviation must be good at "collecting, analyzing and systematizing information about scientific and technical innovations in the field of aviation equipment" [5].

Since the professional standard indicates only the general purpose of learning a foreign language at the university, "the carriculum is determined by higher institutions independently". So the curriculum of the discipline "Foreign Language" in technical universities is compiled on the basis of the Foreign Language Program for non-linguistic universities and faculties [6].

Previously, graduates of technical universities were only expected to read and translate materials from specialized literature. With the development of theory and methodology of teaching foreign languages new competencies are being discovered to characterize the ideal model of a specialist. On the other hand, the initial level of proficiency in a foreign language, thus the actual learning conditions prevent graduates from achieving the stated goals. Otherwise, the curricula could become more complicated than the one in language faculties as it integrates language for general, academic, professional purposes and business communication. We have to admit that the gap between the theory of teaching a foreign language and the actual situation in the audience is increasing. "The task for theorists and researchers, heads of educational institutions is to help teachers navigate the links between theory and practice to increase their motivation, support and ensure their daily educational activities" [7].

Researchers agree that the development of new methods of teaching foreign languages does not give a tangible effect. I. E. Abramova and E. P. Shishmolina characterize the situation in the system of language education in non-linguistic universities as follows: "Such training differs significantly from the training of linguists in specialized language departments. At the same time, there is no teaching in aspects (for example, grammar, writing, phonetics), and the author's approach to teaching the content of the course in English is not always justified. The teacher of the inter-faculty department not only independently organizes the learning process, but also controls its results" [8]. The quality of language education leaves much to be desired because Russia is still included in the group of countries with a low level of English.

As the applicants don't take English exam, their level of communicative competence varies, so that in one group we have students from beginner to upper-intermediate level. Innovative teaching methods, information and communication technologies are undoubtedly intended to increase students' motivation to learn a foreign language but the problem of effective teaching multi-level groups is not solved.

Different level of proficiency in the foreign language of applicants is not balanced with the limited course duration. Some of the challenges cannot be solved by the enthusiasm of teachers developing the textbooks corresponding to the students' needs. G. A. Krasnoshchekova states: "This factor causes certain difficulties in terms of organizing educational activities in the classroom, often forcing teachers to develop parallel activities of different levels of complexity in the same group, which leads to the inability to optimize the educational process" [9].

Low motivation is traditionally considered to be one of the main reasons why graduates of technical universities don't have a good command of English. It is known that "the majority of future engineers have a technical mindset; many have difficulties in studying humanitarian subjects and foreign languages in particular. Therefore, students often pay less attention to foreign language as a subject" [10].

This attitude to English is shared by some researchers. It was proposed, for example, "to move the center of gravity from learning a foreign language to school so that it could save a lot of study time at the university by in-depth study of general subjects before the university or increasing the proportion of students' independent work" [11]. Nowadays most researchers agree that foreign language can and should become a core subject of future professional 
training, an essential professional tool in any subject area [12].

According to the program for non-linguistic universities speaking involves a number of the following skills:

- summarize information from different spoken or written sources;

- use compensating strategies such as paraphrasing to restore failure in the process of communication;

- communicate with a degree of fluency to express personal opinion;

- produce clear, detailed texts on a wide range of subjects.

As for writing students should be able to:

- fill in different forms, make a record of the thoughts as well as the facts from spoken and written sources;

- make a written report and notes for oral presentation;

- design a presentation or information leaflets;

- $\quad$ support contacts via e-mail;

- write a Curriculum Vitae / Resume and the cover letter to apply for a job [6].

As G. V. Perfilova states, "the target goals of the Program are characterized by the transition from the adopted "horizontal" model (linear representation of the overall composition of communicative skills in different types of speech activity) to the "vertical" model structuring skills in accordance with the descriptors of the European communicative language scale competence" [13].

E. N. Solovova states that it makes sense to "create separate programs for humanitarian and technical universities" [14]. If we have a special program for technical universities it could help to tailor the language education according to the requirements of employers. Indeed, "the modern curriculum must meet the interests and needs of both students and their potential employers, thereby being professionally oriented" [9]. The content of professionally-directed foreign language teaching is determined according to the principles of "consistency, continuity, professional significance, professional orientation, accessibility, interdisciplinary context" [15].

\section{Materials and Methods}

The survey was conducted at the Department of Foreign Languages for Aerospace Specialties in Moscow Aviation Institute. The total of 517 students from the first, the second and the third year filled in the Google Forms in the survey in 2018. The goal of our research is:

- $\quad$ to assess the English level of the students;

- to identify the optimal balance of learning a foreign language for General, Academic, Aviation and Business purposes;

- to define the most difficult language aspects for the students;

- to find out the students' learning experience;

- to learn the students opinion about the correlation between the preparation for the Unified State Exam and the students' English level.

- to find out how much time a week the students spend on studying English.

\section{Results}

To assess the level of proficiency in foreign language the students took a multiple choice diagnostic test. According to the results of the survey most students have Pre-Intermediate $(29.4 \%)$ and Intermediate $(27.3 \%)$ level, less students have Beginner (12.4\%) and Elementary level $(15.5 \%)$. Summarizing the results, we emphasize that almost a quarter of students still have a low level of proficiency in a foreign language, some of them are the third-year students.

The Unified State Exam in foreign languages is focused on achieving level B2 or Upper-Intermediate level and it equals to 100 points on the profile exam in a foreign language. According to the data obtained, about $12 \%$ of students of the MAI could potentially study in specialized language universities. Fig. 1 presents the students' answers about the most difficult language aspect.

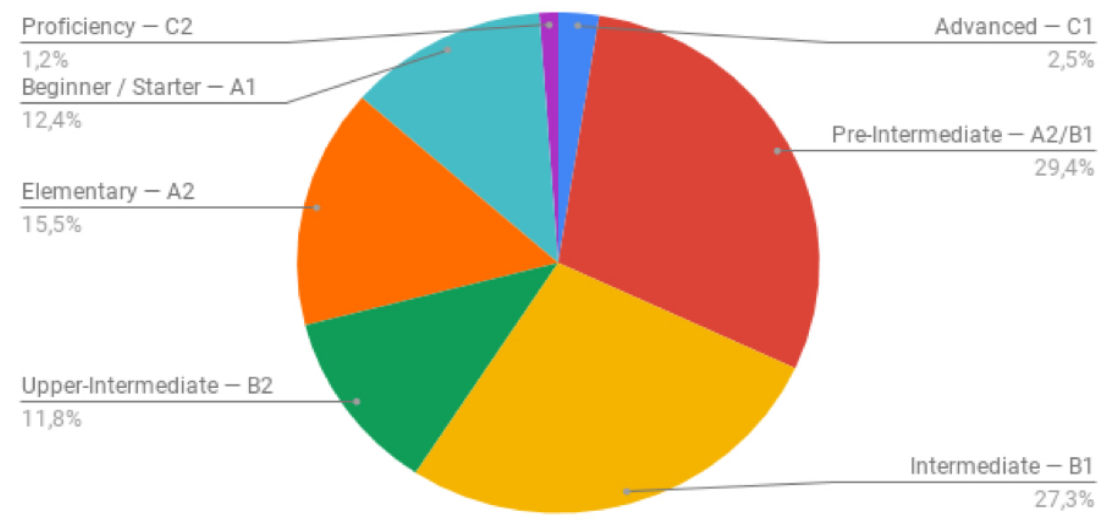

Figure 1. Question no 1. What is your English level? 
Judging by the results of the survey (Table 1) reading is a less complicated type of speech activity for students (12\%). Speaking and listening are interrelated and cause difficulties for $45.6 \%$ and $44.9 \%$ of students respectively. Obviously, one of the reasons for the lack of fluency is caused by the lack of accuracy. This is confirmed by the data obtained, as vocabulary and grammar turned to be the most difficult language aspect (55.9\%).

Table 1. Question no 2. What language aspects are the most difficult for you?

\begin{tabular}{|c|c|c|}
\hline $\begin{array}{c}\text { What language aspects are the most difficult } \\
\text { for you? }\end{array}$ & sum & in \% \\
\hline Listening & 232 & $44.9 \%$ \\
\hline Reading & 62 & $12 \%$ \\
\hline Grammar and vocabulary & 289 & $55.9 \%$ \\
\hline Writing & 159 & $30.8 \%$ \\
\hline Speaking & 236 & $45.6 \%$ \\
\hline
\end{tabular}

Table 2 depicts the student's experience of studying English. All applicants have a different experience and achievements in learning a foreign language. In general, half of the respondents did not study foreign language beyond the school or the university program. The rest of the students attended language courses, had lessons with a tutor or graduated from a school with in-depth study of a foreign language.

Table 2. Question no 3. Where did you study English?

\begin{tabular}{|c|c|c|}
\hline Where did you study English? & sum & in \% \\
\hline I attended language courses & 61 & $11.8 \%$ \\
\hline I had lessons with a tutor & 116 & $22.4 \%$ \\
\hline $\begin{array}{c}\text { I attended school with in-depth study of foreign } \\
\text { languages }\end{array}$ & 45 & $8.7 \%$ \\
\hline $\begin{array}{c}\text { I didn't study English beyond the school and } \\
\text { university curriculum }\end{array}$ & 295 & $57.1 \%$ \\
\hline
\end{tabular}

Table 3 shows the correlation between the preparation for the exam and the students' English level. It goes without saying, that approximately (59.4\%) agreed that they would have improved their level of proficiency in a foreign language if they had taken the Unified State Examination in English.
Table 3. Question no 4. If you had taken the Unified English Exam, would you have enhanced your English Level?

\begin{tabular}{|c|c|c|}
\hline $\begin{array}{c}\text { If you had taken the Unified English Exam, } \\
\text { would you have enhanced your English Level? }\end{array}$ & sum & in \% \\
\hline Yes & 307 & $59.4 \%$ \\
\hline No & 210 & $40.6 \%$ \\
\hline In total: & 517 & $100 \%$ \\
\hline
\end{tabular}

Table 4 describes the students' goals of studying English in the University. The English course at technical universities integrates four content blocks: "Foreign language for general purposes", "Foreign language for academic purposes", "Foreign language for special / professional purposes" and "Foreign language for business communication". In Moscow Aviation Institute students learn Aviation English as a language for special / professional purposes. We were interested to know the students' opinion about their goal of learning a foreign language at the university. Most of the students (64\%) were in favor of studying General English and $45 \%$ of respondents would like to study Aviation English. Fewer students (25\%) consider Business English important for their future career. Some students are interested in Academic English to participate in international exchange programs and studying abroad.

Table 4. Question no 5. What are your language goals of studying English in the University?

\begin{tabular}{|c|c|c|}
\hline $\begin{array}{c}\text { What are your language goals of studying } \\
\text { English in the University? }\end{array}$ & sum & in \% \\
\hline General English & 331 & $64 \%$ \\
\hline Academic English & 102 & $19,7 \%$ \\
\hline Aviation English & 237 & $45,8 \%$ \\
\hline Business English & 129 & $25 \%$ \\
\hline In total: & 517 & $100 \%$ \\
\hline
\end{tabular}

Table 5 reveals how much time a week the students spend on studying English. Analyzing the amount of time that the students spend on studying English a week, it ranges from less than an hour up to more than two hours a week. Unfortunately, $23.6 \%$ of the students do not spend any time on studying English that makes hard to upgrade their English level and improve their communicative competence. 
Table 5. Question no 6. How much time a week do you spend on studying English?

\begin{tabular}{|c|c|c|}
\hline $\begin{array}{l}\text { How much time a week do you spend on } \\
\text { studying English? }\end{array}$ & sum & in $\%$ \\
\hline I don't spend any time on studying English & 122 & $23.6 \%$ \\
\hline $\begin{array}{c}\text { I spend up to } 1 \text { hour on studying English a } \\
\text { week }\end{array}$ & 166 & $32.1 \%$ \\
\hline I spend 1-2 hours on studying English a week & 185 & $35.8 \%$ \\
\hline $\begin{array}{c}\text { I spend more than } 2 \text { hours on studying English } \\
\text { a week }\end{array}$ & 44 & $8.5 \%$ \\
\hline In total: & 517 & $100 \%$ \\
\hline
\end{tabular}

Students were asked an open question about their wishes to improve the teaching of a foreign language at the university. This type of feedback allows to understand the students' expectations and identify the factors that affect the quality of language education at the university. The results of the survey shown that most students are satisfied with the quality of language training at the university, so they do not express any recommendations. For example, they comment as "everything goes well" and "no wishes", sometimes they make jokes "do not take English exam at the session". However, about a third of respondents gave detailed answers explaining their point of view. The students' answers can generally be divided into three categories:

1. To form study groups taking into account the English level and develop individual approach to students.

"It's worthwhile dividing the students into groups according to their English level".

"Please, consider the low level of knowledge."

"Develop a flexible approach to students with different English level."

"Sometimes a more individual approach to each student is required."

2. To improve the oral speech practice in the English lesson at the university:

"Could we have more conversational and practical English?"

"Add more discussions to improve conversational skills."

"We'd like to have more conversations in English with the teacher."

"I'd like to have more speaking practice and improvisation."

"Spend more time listening and speaking instead of doing grammar exercises".

"I would like to experience the language environment in the classroom".

3. To learn a foreign language in the field of professional communication.

"It is necessary to study foreign language in professional context, supported by conversational exercises, involving students in situations that they will encounter in their future professional and everyday life."

"Well, it would be great if we could study English in professional context without all these grammar rules, etc.".

"It's a good idea to add more practical examples to study language in aerospace industry."

"It's necessary to have more English text-books to study professional vocabulary."

"It's important to increase students' interest in the subject. The students must understand that they will need foreign language in adult life. They should master the language not for the sake of passing an examination, but for the sake of self-development".

\section{Discussion}

The results of our research show that there is a correlation between the quality of language education and the students' learning experience. The students continue studying English at the University after many years of learning English at school. If the school-leavers focus on exam preparation, they are likely to enhance their communication skills. Thanks to the exam preparation the student can ask questions, compare photos, write a personal letter and a short essay justifying opinion. The most difficult tasks of the exam teach the students to recognize implicit meaning in authentic texts. It is impossible to get ready for the exam fast. It involves acquiring practical skills as well as understanding the theory. The object of control at the exam is the foreign language communicative competence, including speech, language, socio-cultural, compensatory and general educational competencies. It consists of the following sections: "Listening", "Reading", "Grammar and Vocabulary", "Writing" and "Speaking". Moreover, the communication tasks of the exam are designed to assess communication skills and they may be considered as excellent stimulus for speech practice. The students who had prepared for the Unified State Exam in a foreign language before they entered the University speak more fluently, they don't experience communication barrier. For example, such students are more confident and ready to discuss technical innovations in English at a students' conference.

M. V. Verbitskaya, K. S. Makhmuryan highlighted that it is important to develop spontaneous speech on a daily basis. When working on writing and speaking, it is not possible to "get stuck" in the language aspect of the lessons, it is necessary to proceed to communicative stage, i.e. speech practice, when communicative and meta subject skills integrate [16]. The lack of practice shows that when the students are competent structurally, they still can hardly use the knowledge of grammar to express themselves 
spontaneously. It seems that without fluency in English it takes more time to reach the language goals of engineering education standards at the University.

It is interesting to note that since the Unified State Exam in a foreign language was introduced more attention is paid to writing and listening at the lesson, whereas decades before it had been typical only for schools with in-depth language learning. "With all the shortcomings of the state certification and the Unified State Examination, it is necessary to recognize that these exams have significantly influenced the development of language education in secondary schools, updating the textbooks, and improving the methodological culture of teachers" [14].

\section{Conclusions}

Our study showed that, despite the experience in learning a foreign language the vast majority of students do not speak fluent English. The English level varies from Beginner to Upper-intermediate, thus we deal with multi-level groups with different motivation for studying Aviation, General, Academic and Business English. It is still disputable whether it is possible to fill the knowledge gap without transforming the university English course into the revision of the school curriculum. English course in technical University has its own niche i.e. English in professional context. The quality of language education in technical universities can be upgraded if there is correlation between the program's requirements and the enriching the student's experience of learning English prior the University.

The conducted research revealed that motivation to study English for Specific purposes and the students' prior learning experience and English level contribute to the quality of language education. Further research can also investigate the relationship between formal language education at higher institutions and non-formal learning.

\section{REFERENCES}

[1] S. Zhiyong, G. K. Sidhu, P. Muthukrishnan. College English Language Teaching Reform and EFL Lecturers' Teaching Practice: A Case Study in China. Universal Journal of Educational Research, Vol. 8, No. 1, 230-237, 2020.

[2] T. Yu. Polyakova. Obuchenie inostrannomu yazyku v magistrature inzhenernyh napravlenij, Vestnik FGOU VPO MGAU, Vol. 1, 26-29, 2014.
[3] L. I. Fishman. Specifika deyatel'nosti organov upravleniya obrazovaniem po povysheniyu kachestva obrazovaniya (na primere profilizacii starshej shkoly), Voprosy obrazovaniya, Vol. 3, 42-52, 2009.

[4] ESG. Standards and Guidelines for Quality Assurance in the European Higher Education Area (ESG), Brussels, 2015.

[5] Prikaz Minobrnauki Rossii № 249. «Ob utverzhdenii federal'nogo gosudarstvennogo obrazovatel'nogo standarta vysshego obrazovaniya po napravleniyu podgotovki 24.03.04 Aviastroenie (uroven' bakalavriata)», 2016. Retrieved from: https://minobrnauki.rf

[6] Primernaya programma po discipline «Inostrannyj yazyk» dlya podgotovki bakalavrov (neyazykovye vuzy), IPK MGLU «Rema», Moscow, 2011.

[7] G. Hall. Theory, theories and practice in ELT: 'Believing and doubting': ELT research in action. Bridging the Gap between Research and Classroom Practice, IATEFL, 37-40, 2018.

[8] I. E. Abramova, E. P. Shishmolina. Modelirovanie inoyazychnogo prostranstva pri obuchenii studentov-nelingvistov, Voprosy obrazovaniya, Vol. 3, pp. 132-151, 2017.

[9] G. A. Krasnoshchekova. Obuchenie inostrannomu yazyku studentov inzhenernyh special'nostej na osnove realizacii kontekstnogo podhoda, Otkrytoe obrazovanie, Vol. 3, 81-84, 2014.

[10] O. V. Sirotina. Motivaciya V processe obucheniya inostrannomu yazyku $\mathrm{v}$ tekhnicheskom vuze, Nauchnye trudy KubGTU, Vol. 9, 2015. Retrieved from https://ntk.kubstu.ru/file/508

[11] L. A. Verbickaya, V. B. Kasevich. O modernizacii rossijskoj vysshej shkoly: segodnyashnie problemy i vozmozhnye resheniya, Voprosy obrazovaniya, Vol. 4, 10-22, 2004.

[12] V. Strielkovski, L. S. Kiseleva, E. N. Popova. Determinanty kachestva universitetskogo obrazovaniya: mnenie studentov, Integraciya obrazovaniya, Vol. 2, 220-236, 2018.

[13] G. V. Perfilova. Primernaya programma po discipline «Inostrannyj yazyk» dlya podgotovki bakalavrov (neyazykovye vuzy), Vestnik MGLU, Vol. 12, No. 645, 2012.

[14] E. N. Solovova. Perspektivnye napravleniya razvitiya vuzovskoj metodiki prepodavaniya inostrannyh yazykov, Vestnik MGIMO Universiteta, Vol. 6, No. 33, 67-70, 2013.

[15] S. E. Tsvetkova, I.A. Malinina. Sistematizaciya soderzhaniya inoyazychnoj podgotovki budushchih inzhenerov $\mathrm{v}$ oblasti samolyoto- $\mathrm{i}$ vertolyotostroeniya, Inzhenernoe obrazovanie, Vol. 2, 186-193, 2017.

[16] M. V. Verbickaya, K. S. Mahmuryan. Metodicheskie rekomendacii dlya uchitelej, podgotovlennye na osnove analiza tipichnyh oshibok uchastnikov EGEH 2018 goda po inostrannym yazykam, Pedagogicheskie izmereniya, 2018. 